\title{
The east bank of the Tiber below the Island: two recent advances in the study of early Rome
}

\author{
Albert J. Ammerman*
}

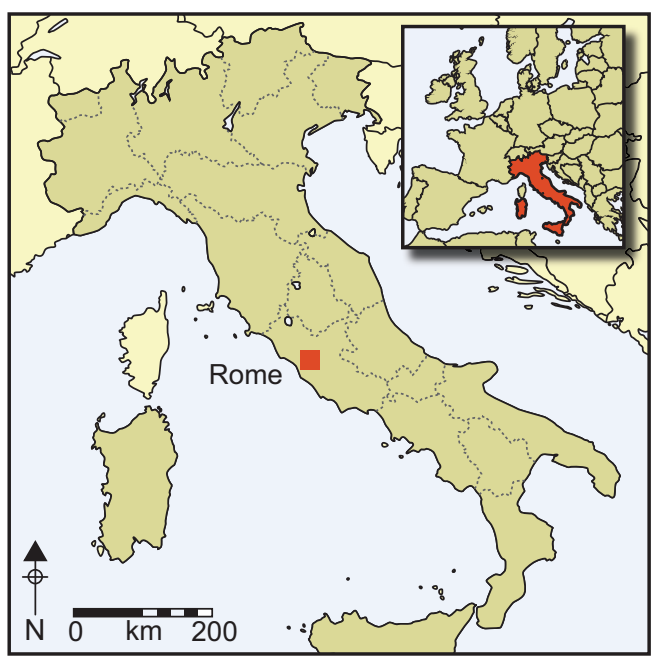

Two recent discoveries on the east bank of the Tiber are of major significance to the study of early Rome: the discovery that the sixthcentury $B C$ riverbank was in a different position to the modern bank, and the finding of a Late Bronze Age site deeply buried adjacent to Sant'Omobono church, the latter reported by Brock and Terrenato (2016). This article reconsiders the Sant'Ombono data in an environmental context, questioning both the previous interpretation of site usage and the provenience of the dating evidence. This reappraisal is placed within a recently developed research theme, namely the transformation of the landscape of early Rome into a cityscape, which involved largescale encroachment on the east bank.

Keywords: Rome, Tiber, Sant'Omobono, environmental archaeology, landscape transformations

\section{Introduction}

The east bank below the Tiber Island is a place of major importance for scholars of the archaeology and topography of ancient Rome. It served as a hub for traffic and trade throughout Roman history. Several major roads passed through its three gates (the Porta Carmentalis, Porta Flumentana and Porta Trigemina), and two of Rome's oldest bridges (the Pons Sublicius and Pons Aemilius) were located there (Richardson 1992: 162-64). Two important and unexpected developments in the study of early Rome have recently come to light, and the aim of this article is to bring these advances together. First, there was the discovery that the east bank has a more dynamic history than previously thought. Figure 1 (blue line) shows that the bank of the Tiber in the sixth century BC stood some $100 \mathrm{~m}$ back from where it is today (Ammerman 2016: fig. 6; see also Ammerman \& Filippi

* Department of the Classics, Colgate University, 13 Oak Drive, Hamilton, NY 13346, USA (Email: aammerman@colgate.edu) 


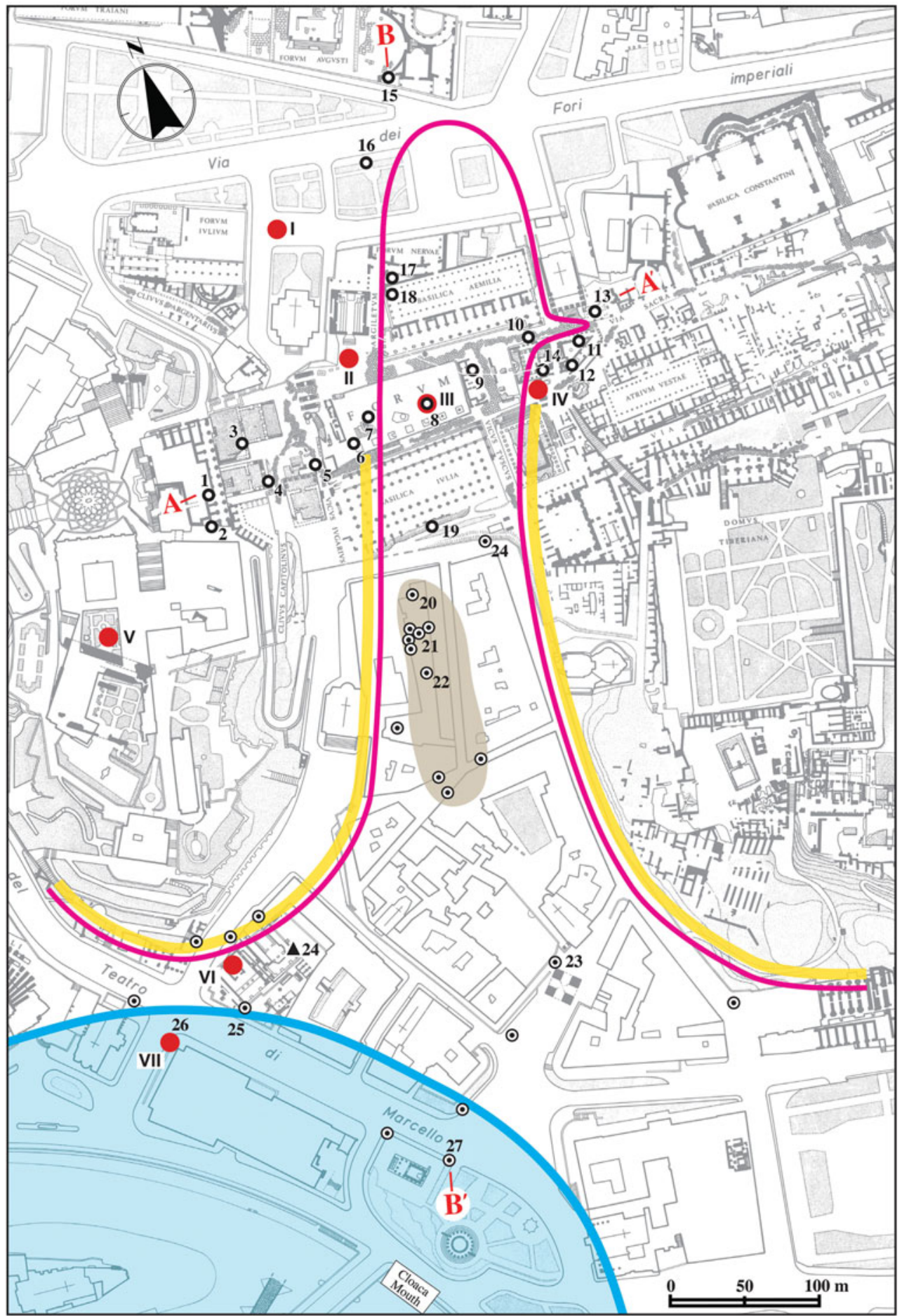

Figure 1. (Please see below.)

(C) Antiquity Publications Ltd, 2018 
2004: 16-17; Ammerman 2006: 299-300, 2013: 171). Three main implications follow from this new discovery: 1) the east bank at that time was located immediately in front of the site known as the Area Sacra di Sant'Omobono; 2) the Forum Boarium was much smaller in size before the Republic (the time before 509 BC, according to Roman literary tradition); and 3) the Romans actively encroached on the riverbank when they built several temples there during the Republic (these three implications are discussed further below). The second major advance on the east bank was the recent discovery (by means of deep coring at Sant'Ombono) of a site dating back to the end of the Bronze Age (see VI in Figure 1; Brock \& Terrenato 2016; Diffendale et al. 2016). When the author first conducted fieldwork in the Forum in 1985, there were only one or two sites (with a modest number of artefacts) that could be attributed to the Late Bronze Age. At that time, archaeologists were still trying to understand what was happening in Rome in the eighth century BCthe time of the foundation of the city, according to Roman literary tradition. Since 1990, major developments in the knowledge of the Bronze Age in Rome have been made through excavations on the east side of the Capitoline Hill and beneath the Forum of Julius Caesar (respectively $\mathrm{V}$ and I in Figure 1; for an overview and bibliography on these two sites, see Brock \& Terrenato 2016: 655-56). Now, for the first time in Rome, there is evidence for an early site that is located in a low area on the bank of the river and that dates to the late second millennium BC.

The east bank of the Tiber below the Island was, of course, the place where the Cloaca Maxima, the great drain of the Forum area, emptied into the river (Figure 1) after crossing the Forum and then running through the Velabrum (the valley between the Capitoline and Palatine Hills). Unfortunately, this low area was subject to inundation when the Tiber rose and was in major flood (Ammerman 1990: 636-38; Aldrete 2007). Figure 1 (red line) indicates the area that was covered with water whenever a flood reached an elevation of $9 \mathrm{~m}$ or more above sea level (asl hereafter) in the Regal period (traditionally 753-510 BC). During the Republic, much of the land on the east bank below the Island was part of the Forum Boarium (Coarelli 1988, 1995: 295-97; Richardson 1992: 162-64). Today, a visitor to this area of Rome can see three standing monuments interspersed in the modern urban built environment: the Ianus Quadrifrons, the Round Temple and the Temple of Portunus (see A, B and C in Figure 2). Less obvious to the visitor is the most important site in the Forum Boarium, at least when it comes to the study of early Rome: the Area Sacra di Sant'Omobono (D in Figure 2; Richardson 1992: 35-37; Brocato \& Terrenato 2012). In the literature, this is also known as the site of the twin Temples of Fortuna and Mater Matuta (Pisani Sartorio 1989: 18-28; Coarelli 1995: 295-97).

Figure 1. Map of early Rome, showing the position of profiles of the natural relief for the Forum basin ( $A-A$ ') and for the lateral valley that runs from the Argiletum to the Tiber $\left(B-B^{\prime}\right)$. Red line: $9 m$ contour indicating the height of the Tiber in major flood. Blue line: position of the Tiber bank in the sixth century BC. Yellow line: exposed shoulder of the gravel beds on the two sides of the valley. Black circle with central dot: the 24 deep cores made in the Velabrum. Beige: clay beds in the Velabrum. Black circles: cores made in the Forum basin and the Argiletum. Red circles: sites that have produced archaeological artefacts (or ${ }^{14} C$ dates), which date to the Late Bronze Age or earlier. The identification and starting elevation of each core with an Arabic numeral can be found in Ammerman and Filippi (2004: 14).

(C) Antiquity Publications Ltd, 2018 


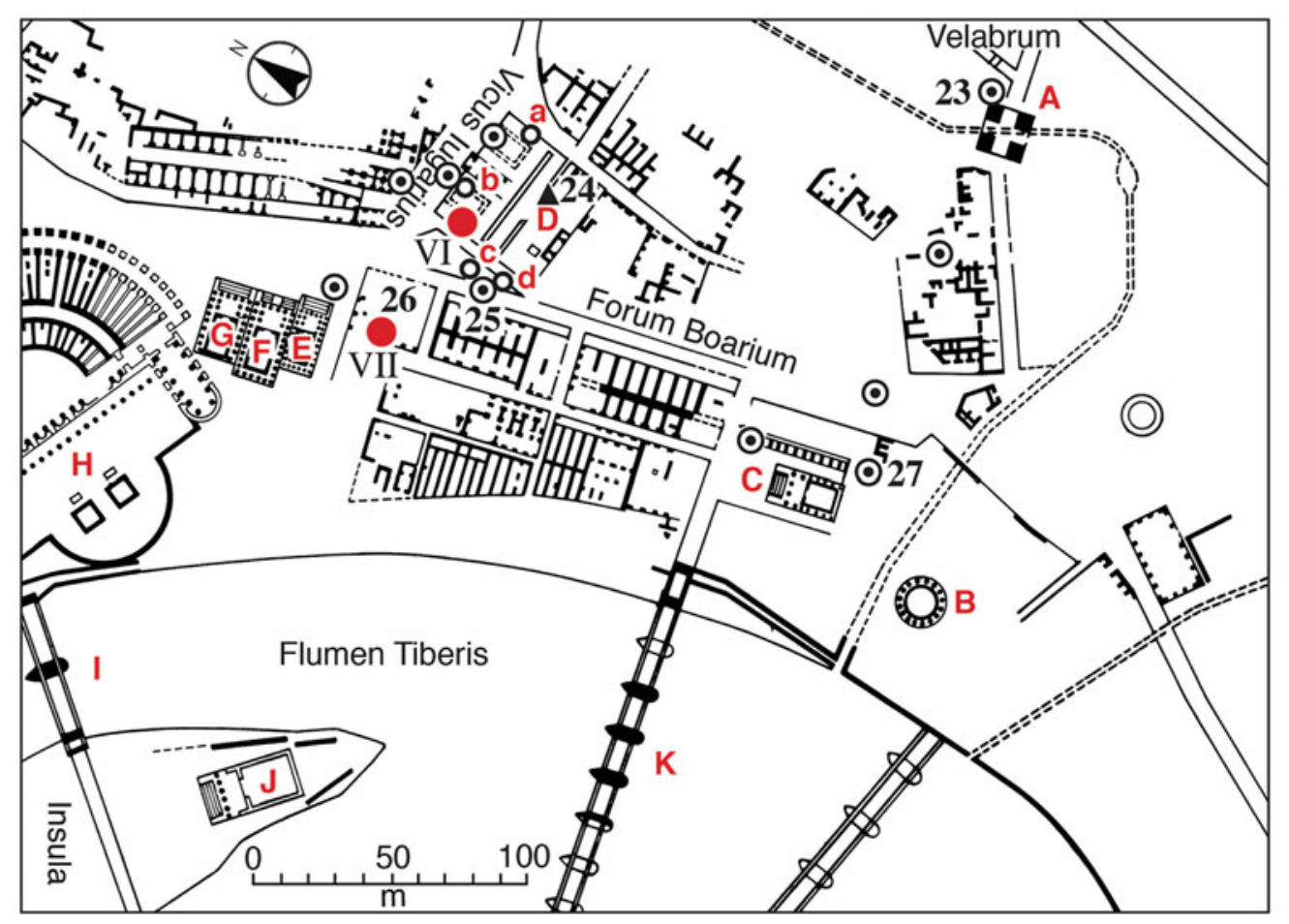

Figure 2. Map of the Forum Boarium and nearby areas (after Coarelli 1988: fig. 1). The monuments and bridges are given with red letters as follows: A) Ianus Quadrifrons; B) the Round Temple; C) Temple of Portunus; D) Temple of Fortuna (where percussion core OS 17 was made in 2013); E) Temple of Spes; F) Temple of Juno Sospita; G) Temple of Janus; H) Theatre of Marcellus; I) Pons Fabricius; J) Temple of Aesculapius; and K) Pons Aemilius. For the cores shown on this map, see the text and the full caption of the figure given at the end of the online supplementary material.

To gain a better appreciation of the scale of change in the position of the riverbank between the sixth century $\mathrm{BC}$ and the end of the Republic, it is useful to compare the position of core 25 in Figures 1 and 2. It will be recalled that scholars who had previously worked on the topography of early Rome had all assumed that the bank of the Tiber had always stood essentially in the place where it is seen today. This is what we see on the maps of early Rome drawn by Lanciani (1897: fig. 1), Gjerstad (1960: fig. 1), Tortorici (1991: fig. 7) and Quilici (1995: fig. 1). The author once held this view as well. What was recovered from two deep cores made in 1998 thus came as a complete surprise (see cores 25 and 26 in Figure 1, which correspond with cores 13 and 14 in Figure 3; see Table S1 in the online supplementary material (OSM)). This finding was then confirmed in 2003 when four more deep cores were taken in the same area (cores 18, 19, 20 and 23 in Figure 3), which again produced long sequences of alluvial sediments. The OSM provides further information about the three cycles of coring in the Velabrum, which led to the 24 deep, machine-made cores shown in Figure 3, and their connection with the new theme of transforming the landscape in the study of ancient Rome (Ammerman 2013: 177-80). Our understanding of the east bank now took a new and rather different form: that is, encroachment on the river and the construction of several temples between the fourth and second centuries BC.

(C) Antiquity Publications Ltd, 2018 


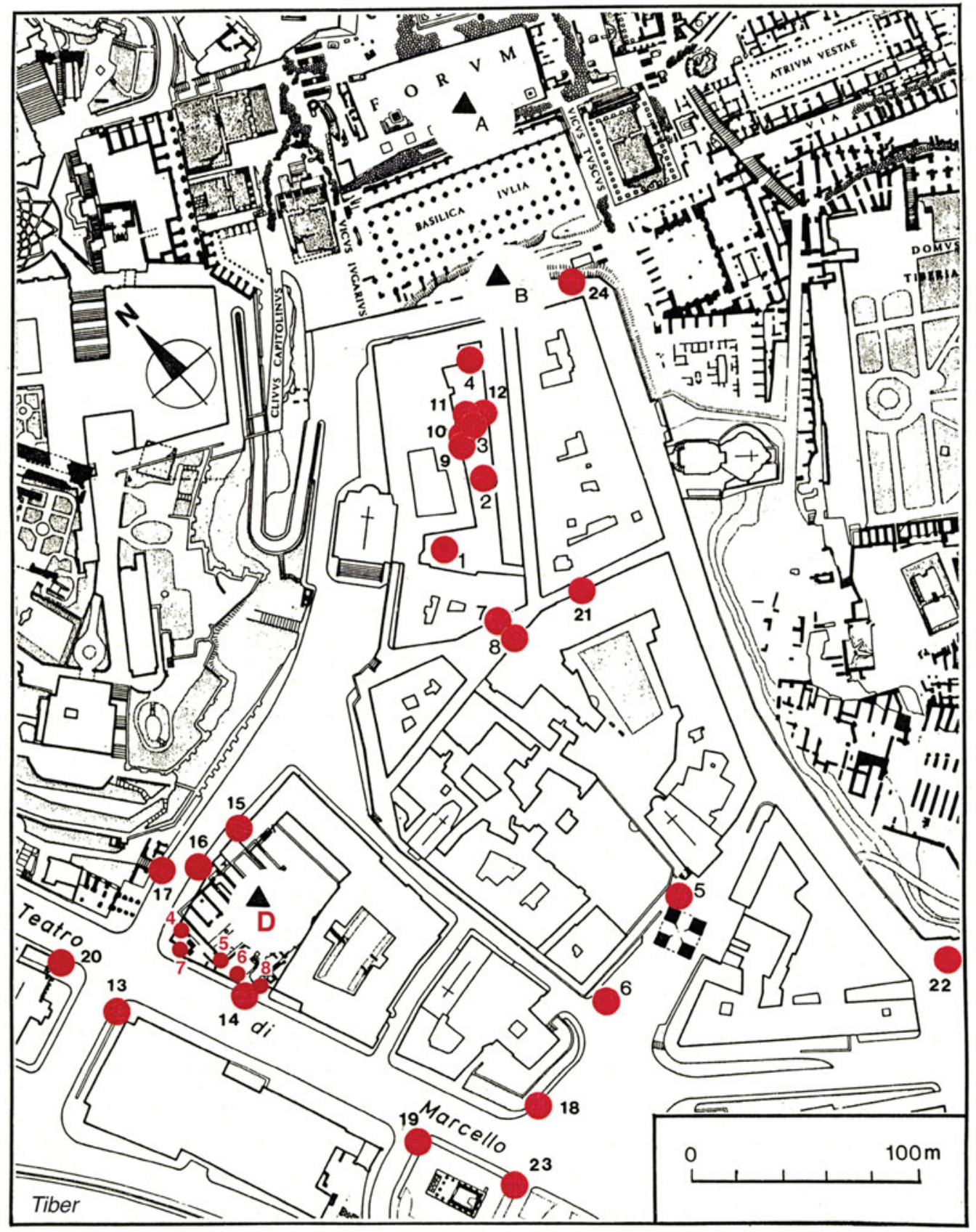

Figure 3. Map of the 24 deep cores made in the Velabrum and near the Tiber. The cores were made in three cycles: cores 1-8 in 1996, cores 9-17 in 1998 and cores 18-24 in 2003 (the black numbers). For the corresponding number of each core when it is shown in Figures 1-2, see Table S1 in the online supplementary material. The map also shows the locations of the five percussion cores (SO 4-SO 8; the red numbers) made on the west side of the site of Sant'Omobono in 1998; the archaic temple is located at $D$, as is also shown in Figure 2. 
Knowledge of the third dimension of sites in the Forum Boarium was quite limited for many years. Indeed, it was only in 1989 that elevations cited with proper reference to sea level made their first appearance in the catalogue of the exhibition: Il viver quotidiano in Roma arcaica (Pisani Sartorio 1989: 18-28; on the value of the benchmark at the site, see Ammerman \& Filippi 2004: 16). Today, the third dimension is viewed as key to the study of the east bank. Furthermore, the area presents the archaeologist with a major challenge: the high position of the modern water table. At the site of Sant'Omobono, it commonly stands at about $10 \mathrm{~m}$ asl. This means that excavation involving any significant depth in the ground can only be carried out with pumps in operation. Thus, this is why coring plays such an important role in the study of early Rome in this part of the city. The high water table also helps to explain why so few excavations at sites in the Forum Boarium have ever brought to light archaeological levels that date to before the fourth century BC (for a catalogue of the sites in the Velabrum and the Forum Boarium, see Cressidi 1984). In fact, the only site in this part of Rome where excavations have reached levels dating to the sixth century $\mathrm{BC}$ is the one at Sant'Omobono. Using the Cobra method of percussion coring to go even deeper at the site, there was the chance to recover seeds from dark anthropic soil horizons (at elevations in the range between 3.2 and $6 \mathrm{~m}$ asl), which have produced four AMS dates whose calibrated ages go back to the end of the Bronze Age (Brock \& Terrenato 2016: 659-62).

Given the significance of the new findings at Sant'Omobono, the results were quickly brought to publication. The present article re-examines the new evidence and produces a different interpretation of the site. By way of background, a brief summary of the fieldwork is given here. In July 2014, five percussion cores were made in the limited space available in the base of the narrow, deep sounding, called A7, at Sant'Omobono (Brock \& Terrenato 2016: 660; fig. 5; cores SO 22-26). The cores all started at more or less the same elevation (approximately $7.6 \mathrm{~m}$ asl); that is, in a position well below the modern water table. In this context, the only way to investigate deeper into the ground was by means of coring. There is a schematic diagram in Brock and Terrenato's paper (2016: 661, fig. 6) that gives the sequence of dark stratigraphic units observed in the cores. At first glance, the relationship between the three dark units (called deposits A, B and C) in the respective cores seems to be in disarray, or even discordant: the units do not line up neatly across the cores. There is, however, a clear and interesting pattern in the dark soil units that is not considered in the original article. This pattern can be recognised when the cores are placed in the context of the sloping relief of the area where the seeds were recovered. In terms of chronology, all four of the dated seeds yield calibrated ages that cluster between $c .1225$ and $930 \mathrm{BC}$ (Brock \& Terrenato 2016: 659, tab. 2). In short, the authors claim to have found a lowlying Late Bronze Age settlement located near the river. What Brock and Terrenato (2016) do not take into account is the environmental setting of the place where the seeds were recovered and, in particular, the nearby gravel beds at the base of the Capitoline Hill that occur just to the north of trench A7. As is explained below, there is good reason, based on environmental evidence, to think that this place was not well suited to year-round settlement or habitation. Instead, it would be better to interpret what has been found as a special activity site - one that was inundated at those times of the year when the Tiber was in major flood (Ammerman 1990: 636-38; Aldrete 2007: 51-90).

(C) Antiquity Publications Ltd, 2018 


\section{Placing the dated seeds in environmental context}

There are two separate issues that need to be considered here. The first concerns the setting in which the fieldwork itself was carried out at Sant'Omobono over three field seasons (2012-2014). Major problems arose at several points during the planning and execution of the work in 2013 (see the OSM, where these problems are mentioned briefly in the context of the author's previous investigations based on coring in Rome, starting with the Forum in 1985 (Ammerman 1990) and the design of the coring project done over three years at Sant'Omobono). In light of the problems in 2013, the author had to take a more active hand in guiding and carrying out the fieldwork in 2014. The second issue involves the environmental context from which the seeds were recovered at Sant'Omobono. To place the seeds recovered from the five cores made at the base of trench A7 in an environmental context, it is best to start with the oldest geological unit on the north side of Sant'Omobono: the white indurated gravels that occur at the base of the Capitoline Hill (e.g. Alvarez et al. 1996: fig. 2; Ammerman \& Terrenato 1996: fig. 6; Ammerman 1998: fig. 3, 2013: fig. 11.1). This geological unit, whose formation is linked with a course of the palaeo-Tiber dating to well over 500000 years ago, constitutes the foundations of the Capitoline Hill. With a thickness of approximately $10 \mathrm{~m}$, the base of the gravel beds occurs at close to sea level today, and their top stands at an elevation of around $10 \mathrm{~m}$ asl. In historical terms, the gravel beds at the base of the Capitoline and Palatine Hills were important to the early Romans as an aquifer for springs around the Forum. They were also used for laying down the first gravel pavements of the Forum.

At the same time, the tops of the exposed gravel beds on the two sides of the Velabrum served as natural lines of communication between the river and the Forum in early Rome (the yellow lines on opposite sides of the valley in Figure 1). In effect, they were the precursors of two important streets in ancient Rome: the Vicus Tuscus and the Vicus Iugarius (see Figure 2, where the latter passes just on the north side of Sant'Omobono). Cores 15 and 16 in Figure 3 (shown without numbers in Figure 2) were taken along the south side of the modern street, where the tops of the gravel beds occur at elevations of 11.4 and $10.8 \mathrm{~m}$ asl respectively. At point $\mathrm{b}$ in Figure 2 (where core SO 31 was taken), the top of the gravel beds stands in a slightly lower position-at $10.2 \mathrm{~m}$ asl. The distance between point $b$ and trench A7, where the five cores were made (VI in Figure 2), is only $14 \mathrm{~m}$. The difference in height between the lowest, dated seed (at around $3.26 \mathrm{~m}$ asl in core SO 24) and the top of the gravel beds at $\mathrm{b}$ is approximately $6.95 \mathrm{~m}$. This means that there is an average slope between the two points of almost 1 in 2 . In the case of the dated seed in the highest position (at an elevation of about $5.9 \mathrm{~m}$ asl in core $\mathrm{SO} 22$ ), the difference in height between the two points ( $\mathrm{b}$ and the dated sample) is approximately $4.3 \mathrm{~m}$, which yields an average slope of about 1 in 3 . In short, there was once a steep slope rising up to the north-east just behind trench A7.

As documented by core $\mathrm{SO} 32$ - taken just a few metres to the south-west of b in Figure 2 and also at a location to the east in the same figure (where core SO 36 was taken) - there is good evidence for the erosion of the then-exposed gravel beds and the deposition of colluvial gravel on the slope. There is also evidence that the colluvial gravels could extend locally as far down the slope as the area of trench 7A. Core SO 25, the shortest of the five cores in the (C) Antiquity Publications Ltd, 2018 
schematic diagram (Brock \& Terrenato 2016: fig. 6), was blocked by colluvial gravels at an elevation of approximately 5.12m asl. Thus, Brock and Terrenato's (2016: 659) assertion that the sediments that occur at A7 derive only from alluvial processes is incorrect: pieces of colluvial gravel made their way down the slope and became incorporated in the alluvial sediments there. The striking feature of the formation of the site is the rapid inflation of the land surface in area A7 over a comparatively short span of time. As observed in the case of core SO 24, in which all three of the dark units are present in the schematic diagram, the difference in height between the top of the upper unit (A) and the base of the lower one (C) is about $2.4 \mathrm{~m}$. The four AMS dates currently available indicate that the build-up of the land surface took place over a span of two or three centuries. The chronology of each of the three dark soil horizons (A, B and C) is, in many respects, still unresolved. In retrospect, it was somewhat imprudent for a preliminary study to be based on AMS dates obtained from just four seed samples, when six or eight seeds could have been dated.

Does further inspection of the schematic diagram lend added support for the existence of such a slope in the context of trench A7, the place where the five cores were made? The answer to this question is affirmative. In light of the slope observed between point $\mathrm{b}$ and trench A7, the core located farthest to the north-east (core SO 23) should be the one that occurs highest up the slope (see the plan of trench A7 and also the schematic diagram in the OSM). Conversely, the core located farther to the south and west on the plan-core SO 24-should be the one lowest on the slope. The distance between the centres of these two cores is just below $1 \mathrm{~m}$. The difference in elevation between the tops of the upper dark unit (A) in these two cores is around $0.35 \mathrm{~m}$, which gives a slope of approximately 1 in 3. When a comparison is made between the tops of the middle dark unit (B) in the same two cores, the difference is $0.25 \mathrm{~m}$, which yields a slope of 1 in 4 . The values for the slope are much the same in both cases, and they are similar to the slope of 1 in 3 mentioned above (between point $b$ and the highest, dated seed sample in trench A7). Thus, the same basic result is obtained from the two lines of analysis. There are, of course, limitations to the measurements that can be made when working with such a small, schematic diagram. Hence, the numbers cited here should be taken as approximate. The pattern is, however, a consistent one: note, for example, that the top of unit A in core SO 22 stands in height between the top of core SO 23 (higher) and the top of core SO 24 (lower). This is just what one would expect to find. In short, the schematic diagram does have a clear pattern, and one that is relatively easy to read when trench A7 is placed in an environmental context.

\section{Discussion}

In their introduction, Brock and Terrenato (2016: 654-56) review the literature on Late Bronze Age sites in Rome and note the shortage of settlement dating to that time. The site where the cores were made is clearly one of past human activity. The question then becomes whether or not it makes sense to interpret what was found in trench A7 as evidence for an early settlement. There are three solid reasons to doubt this line of interpretation. First, as already mentioned, the slope in the area was too steep to make it a good place for continual habitation. It would have been difficult to live there on a year-round basis and conduct daily life on a slope of 1 in 4 . Second, during the winter months when it often rains in 
Rome, the water runoff on the slope would have made it too wet for settlement. Finally, the land elevations at the time were below the heights of major Tiber floods. Any Late Bronze Age settlement would have been inundated for several days at a time from year to year. If a wattle-and-daub house or hut was built there, its thatched roof and earthen walls would have been washed away by a major flood, and the structure would have to be rebuilt time after time. Recall that the dated seeds have elevations in the range of 3.2-6m asl. Even if the levels of major flood events of the Tiber were slightly lower in the Late Bronze Age-7-8m rather than $9 \mathrm{~m}$ in elevation for the Regal period (as shown in Figure 1) — the area would still have been regularly flooded. Thus, the balance of the evidence is against an interpretation of the site as a settlement.

Instead, I propose that this was a special activity site-one whose purpose was connected with the river. The east bank below the Island was, of course, a good place to ford the Tiber. In this context, it is possible to propose that a certain range of activities was carried out at the early site. For example, the slightly elevated slope at Sant'Omobono could have served as a good place to keep watch over the river and the people who might want to cross it. There may even have been a night watch on the upper slope overlooking the river, with the ashes and charcoal fragments from its fires contributing to the formation of the dark anthropic soils that occur at the site. The site might have been a place on the east bank to collect tribute for passage from those who were allowed to cross the river. Another possibility is that the site was a place where ferrymen could rest and take refreshment between their trips across the river (much like the boatmen in Venice on the banks of the Grand Canal today). Still another activity to consider is the possibility that the site was a place of exchange. If further deep coring at Sant'Omobono confirms this, the early site could be seen as a modest forerunner of the emporium on the east bank in the sixth century BC (Giovannini 1985; Coarelli 1995). Given the thin nature of the archaeological evidence, however, it is premature to say which of these different possible activities were undertaken at the site in the Late Bronze Age. Here it is worth adding that freshwater in all probability seeped from the aquifer in the gravel beds located just upslope from trench A7. Indeed, there might have even been a small spring in the area, which would have given the site an added attraction.

An additional important question arises when trench A7 is placed in an environmental context. It concerns whether or not the seeds occurred in situ. Brock and Terrenato (2016: 659) use the term 'deposit' in describing the dark stratigraphic units containing seeds. They also state that "the anthropic layers" (2016: 659) formed in situ on the banks of the Tiber, but the seeds were in fact recovered on a slope with quite a steep gradient. There is also evidence for the occurrence of colluvial gravel on the slope: recall that core SO 25 was blocked by such gravel. Thus, site formation in the area of trench A7 involved a combination of two quite different processes: alluviation and colluviation. Although a full discussion of each geomorphological process is beyond the scope of this article, the point here is simply to note that both processes entail fairly high levels of energy, and the question of whether the seeds occurred in situ warrants further attention (see section 5 in the OSM).

The previous article also introduces an issue regarding the topography of ancient Rome. Specifically, where does the toponym "Forum Boarium valley" (Brock \& Terrenato 2016: 656-57) belong? Prior to the Republic, the site known as the Area Sacra di Sant'Omobono

(C) Antiquity Publications Ltd, 2018 
was situated on the east bank of the Tiber, with its back against the foot of the Capitoline Hill. What is unclear is where the so-called 'Forum Boarium valley' is located on the map of Rome in the sixth century BC. This is not a term that we find in the ancient sources, nor is it found in dictionaries on the topography of ancient Rome. Instead, there is the valley called the Velabrum that runs from the Forum to the Tiber (Richardson 1992: 406-407; Ammerman 1999: 101-102). There is also the valley between the Palatine and Aventine Hills that passes through the area of the Circus Maximus on its way to the Tiber. This is often called the Vallis Murcia by modern scholars (Richardson 1992: 260). And there is, of course, the much larger valley of the Tiber itself. Where, in all of this, does the Forum Boarium valley find its place within the topography of the three valleys already in the literature? This is a technical matter that can surely be resolved.

The line of enquiry of much greater interest in the modern study of the Forum Boarium is that of working out the steps in the encroachment on the Tiber. That few studies have yet to address this research topic is fully understandable, as the concept of encroachment on the riverbanks is a recent development. Previously, scholars interested in the topography of Rome assumed that the east bank of the Tiber stood essentially in the same place over the centuries. Traditionally, this was a working assumption that few scholars questioned, and reflects what has been called "the syndrome of the eternal city" (Ammerman 2006: 307): the mental habit of imagining the city of Rome as if it were a timeless, unchanging place. The notable exception here is the view of the infinite mutability of Rome over the centuries held by the sixteenth-century French essayist Michel de Montaigne (Ammerman 2006: 300-303). With the recent development of studies on the transformation of the landscape in ancient Rome, there has been a shift towards a more dynamic perspective. For the east bank below the Island, we now know that the situation was quite different in the sixth century BC. What is observed on the modern east bank is the consequence of encroachment there since that time. In retrospect, encroachment on the Tiber should not come as such a surprise; it is just what other waterfront cities around the world have historically done. In short, Rome now joins this club.

In closing, it is worth saying a few more words about encroachment as it relates specifically to the east bank below the Island. To begin with, encroachment did not comprise one large project, as was the case in transforming the Forum basin into the Forum. Instead, encroachment on the east bank took place in a series of phases, unfolding over a considerable span of time. This can be appreciated if we consider two of the Republican temples standing on the banks of the Tiber. In the case of the Temple of Portunus, the construction of the first temple on the site began in the second half of the fourth century $\mathrm{BC}$, and its podium was subsequently raised in height when the temple was rebuilt (see C in Figure 1; Ziolkowski 1992: 138-39; Buzzetti 1999: 153-54). In contrast, the Round Temple is more recent: its construction is attributed to the second half of the second century BC (see B in Figure 1; Richardson 1992: 188-89). In addition, as one would expect on the basis of its younger age, the Round Temple is today nearer to the Tiber than the Temple of Portunus, which is set farther back. In brief, there is good evidence for active encroachment on the east bank from the fourth to the second centuries BC. While this arc of time appears to be at the heart of encroachment on the east bank, some steps had already been taken in the fifth century BC, and they continued well into the days of the Empire. What was 
involved is a story of considerable length and complexity. Further effort in the twenty-first century-involving new excavations, more deep cores and the re-reading of the ancient sources-is required to make headway in piecing this rich story together. The sheer scale of the landscape transformation is impressive. The encroachment took place on a front of some $300 \mathrm{~m}$ (the distance between B and G in Figure 2); its forward extension went out approximately $100 \mathrm{~m}$ into the river. At the peak of encroachment, ground levels rose in elevation to $14 \mathrm{~m}$ or more (particularly in those places where a temple was built along the river, so that it could stand above the high levels of Tiber floods). On the whole, this was a truly massive undertaking - and one that we are just starting to appreciate in the study of ancient Rome.

\section{Supplementary material}

To view supplementary material for this article, please visit https://doi.org/10.15184/aqy. 2017.211

\section{References}

Aldrete, G.S. 2007. Floods of the Tiber in ancient Rome. Baltimore (MD): Johns Hopkins University Press.

Alvarez, W., A.J. Ammerman, P.R. Renne, D.B. Karner, N. Terrenato \& A. Montanari. 1996. Quaternary fluvial-volcanic stratigraphy and geochronology of the Capitoline Hill in Rome. Geology 24: 751-54. https://doi.org/10.1130/00917613(1996)024<0751:QFVSAG > 2.3.CO;2

Ammerman, A.J. 1990. On the origins of the Forum. American Journal of Archaeology 94: 627-45. https://doi.org/10.2307/505123

- 1998. Environmental archaeology in the Velabrum, Rome: interim report. Journal of Roman Archaeology 11: 213-23.

https://doi.org/10.1017/S1047759400017268

- 1999. Velabrum (environmental setting), in E.M. Steinby (ed.) Lexicon Topographicum Urbis Romae 5: 101-102. Rome: Quasar.

- 2006. Adding time to Rome's imago, in L. Haselberger \& J. Humphrey (ed.) Imaging ancient Rome: 297-308. Portsmouth (RI): Journal of Roman Archaeology.

- 2013. Looking at early Rome with fresh eyes: transforming the landscape, in J.D. Evans (ed.) $A$ companion to the archaeology of the Roman Republic: 169-80. Oxford: Wiley Blackwell. https://doi.org/10.1002/9781118557129

- 2016. On Giacomo Boni, the origins of the Forum and where we stand today. Journal of Roman Archaeology 29: 209-311.
Ammerman, A.J. \& D. Filippi. 2004. Dal Tevere all'Argileto: nuove osservazioni. Bullettino della Commissione Archaeologica Comunale di Roma 105: 7-28.

Ammerman, A.J. \& N. Terrenato. 1996. Nuove osservazioni sul colle Capitolino. Bullettino della Commissione Archaeologica Comunale di Roma 97: 35-46.

Brocato, P. \&. N. Terrenato (ed.). 2012. Nuove ricerche noll'area archeological di S. Omobono a Roma. Arcavacata di Rende: University of Calabria.

Brock, A.L. \& N. Terrenato. 2016. Rome in the Bronze Age: late second-millennium BC radiocarbon dates from the Forum Boarium. Antiquity 90: 654-64. https://doi.org/10.15184/aqy.2016.65

Buzzetti, C. 1999. Portunus, Aedes, in E.M. Steinby (ed.) Lexicon Topographicum Urbis Romae 4: 153-54. Rome: Quasar.

CoArelli, F. 1988. Il Foro Boario. Roma: Quasar.

- 1995. Forum Boarium, in E.M. Steinby (ed.) Lexicon Topographicum Urbis Romae 2: 295-97. Rome: Quasar.

Cressidi, G. 1984. Il Foro Boario e il Velabro. Bullettino della Commissione Archaeologica Comunale di Roma 89: 249-96.

Diffendale, D.P., P. Brocato, N. Terrenato \& A. BRock. 2016. Sant'Omobono: an interim status quaestionis. Journal of Roman Archaeology 29: 7-42. https://doi.org/10.1017/S1047759400072032

Giovannini, A. 1985. Le sel et la fortune de Rome. Athenaeum 63: 373-86. 
GJerstad, E. 1960. Early Rome III. Lund: C.W.K. Gleerup.

LANCIANI, R. 1897. The ruins and excavations of ancient Rome. New York: Bell.

Pisani SARTorio, G. 1989. Mater Matuta e Fortuna, in Il viver quotidiano in Roma arcaica: 18-28. Roma: Procom.

Quilici, L. 1995. Il plastico di Roma arcaica al Museo della Civiltà Romana. Ocnus 3: 143-55.
Richardson, L. 1992. A new topographical dictionary of ancient Rome. Baltimore (MD): Johns Hopkins University Press.

Tortorici, E. 1991. Argiletum. Rome: 'L’Erma' di Bretschneider.

Ziolkowski, A. 1992. The temples of mid-Republican Rome and their historical and topographical context. Rome: 'L'Erma' di Bretschneider.

Received: 27 January 2017; Accepted: 14 February 2017; Revised: 20 March 2017 